УДк 632.93:632.915:632.913

DOI https://doi.org/10.32848/agrar.innov.2021.8.10

\title{
ФІТОСАНІТАРНІ НАСЛІДКИ АНТРОПОГЕННОЇ ТРАНСФОРМАЦІЇ АГРОЕКОСИСТЕМ
}

\author{
МЕЛЬНИЧУК Ф.С. - доктор сільськогосподарських наук, директор \\ https://orcid.org/0000-0003-2711-5185 \\ Державне підприємство «Центральна лабораторія якості води та ґрунтів» \\ Інституту водних проблем і меліорації Національної академії аграрних наук України \\ ГОРдІєнкО О.В. - кандидат сільськогосподарських наук \\ https://orcid.org/ 0000-0001-9488-916X \\ Державне підприємство «Центральна лабораторія якості води та ґрунтів» \\ Інституту водних проблем і меліорації Національної академії аграрних наук України \\ АлєкСєЄВА С.А. - кандидат сільськогосподарських наук \\ https://orcid.org0000-0001-8463-4614 \\ Державне підприємство «Центральна лабораторія якості води та ґрунтів» \\ Інституту водних проблем і меліорації Національної академії аграрних наук України \\ ОСТРИк І.М. - кандидат сільськогосподарських наук \\ https://orcid.org/0000-0002-1083-8080 \\ Державне підприємство «Центральна лабораторія якості води та ґрунтів» \\ Інституту водних проблем і меліорації Національної академії аграрних наук України \\ ШАТКОВСЬКА К.Б. - науковий співробітник \\ https://orcid.org/0000-0002-7922-2698 \\ Інститут водних проблем і меліорації Національної академії аграрних наук України \\ ГУЛЕНКО О.І. - аспірант \\ https://orcid.org/0000-0002-1007-5677 \\ Інститут водних проблем і меліорації Національної академії аграрних наук України
}

Постановка проблеми. $\mathrm{Y}$ період $\mathrm{XX}$ - початок XXI століття за прискорених темпів розвитку науково-технічного прогресу надзвичайно ускладнилися проблеми взаємодії природи і суспільства внаслідок інтенсифікації промислового виробництва та сільського господарства, зросла антропогенна дія на глобальні природні процеси в біосфері Землі. Більшість із цих процесів у міру свого прояву набули загальнопланетарного характеру. За таких умов відбувається прогресуюче погіршення фітосанітарного стану посівів сільськогосподарських культур.

Сільське господарство $€$ найтривалішим і залишається найпотужнішим чинником трансформації наземних екосистем. Спостережуване нині загострення екологічної ситуації $€$ однією з основних глобальних проблем сучасності. Розвиток сільського господарства, особливо у період інтенсивного залучення різноманітних ресурсів для підвищення продуктивності культурних рослин, надає зростаючий вплив на навколишнє середовище, що призводить до серйозних порушень у структурі видового складу членистоногих, фрітопатогенів і бур'янів, появи нових шкідливих (інвазійних) видів. У цьому зв'язку найбільш динамічним напрямом розвитку аграрної науки XXI століття $€$ екологізація сільськогосподарського виробництва, що знайшло своє відображення в концепціях адаптивно-ландшафтного та органічного землеробства [1-4].

Сільськогосподарська галузь $€$ потужним фактором впливу на навколишнє середовище, а за рівнем антропогенного навантаження, за оцінками науковців, знаходиться серед лідерів. Передбачення всіх наслідків натиску людської діяльності на навколишнє середовище зусиллями лише науки стає все складнішим, навіть у межах невеликого регіону. До появи виробничої діяльності людини жодна жива істота не могла впливати на гомеостаз екосистем. Перепоною на шляху такого впливу стояв природний добір, під час якого відбувалися постійна зміна норм реакції усіх видів рослин, тварин і мікроорганізмів, збалансування взаємовідношень між ними, коеволюція та підтримування відносної стабільності пам'яті в екосистемі протягом століть. Лише з появою Homo sapiens започатковано історичні зміни у природі, які зрештою стали загрожувати відносній стабільності екосистем і нормальному існуванню самої людини [5].

Під антропогенною трансформацією природно-господарських систем слід розуміти зміну ландшафтів під впливом господарської діяльності людини. Рівень антропогенного трансформування природно-господарських систем $є$ інтегральною характеристикою, що враховує не лише зміни структури ландшафту загалом, але і рівень хімічного забруднення його компонентів, а також зміни видового складу флори та фауни. Хоча ці проблеми здавна привертали до себе увагу науковців, але й надалі вони залишаються актуальними в науково-методичному і практичному аспектах [6].

Аналіз останніх досліджень і публікацій. Концептуальні основи теоретичного і практичного питання захисту рослин сформувалися в кінці XX - на початку XXI століття, що передбачали гармонійне поєднання всіх наявних методів і засобів, спрямованих на довгострокове стримування шкідливих видів біотрофрів на рівні нижче економічного порогу шкодочинності (ЕПШ). Водночас ця система, хоч і базується на переважному використанні нехімічних засобів захисту рослин, фактично націлена на отримання високого захисного ефекту без всебічної оцінки антропогенних наслідків застосовуваних засобів та екологічного ризику. 
У XX столітті, особливо за останні десятиліття, зростаючий техногенний вплив призвів до збільшення кількості природних стихійних явищ. Про те, що господарська діяльність людини стала активним антропогенним фактором, було підкреслено у 20-30-их роках B.I. Вернадським [7], хоча ще раніше про значення антропогенних фракторів у перетворенні Землі говорили Дж. Марш [8], А.І. Воєйков [6]. Цій проблемі були присвячені їхні численні роботи.

Вплив антропогенної трансформації агроекосистем та її фрітосанітарні наслідки надалі вивчали такі науковці, як А.Г. Васильєв, Н.А. Вилкова, І.Д. Шапіро, А.А. Жученко, Н.П. Федоренко, Н.Ф. Реймерс, Е.В. Гірусов, В.В. Жеріхін, Городков К.Б. та інші [9-14].

За свідченням А.Г. Васильєва [9], сучасна діяльність людини за довгої антропогенної дії на екосистеми прискорює процеси генотипової зміни популяцій консументів. Особливо помітно це під час спостереження за домінантними видами тварин та рослин, які можуть слугувати індикаторами у разі проведення біологічного моніторингу негативних процесів, що відбуваються у трансформованих екосистемах.

Аналізуючи негативні наслідки рекреативної антропогенної дії на біосферу, А.А. Жученко [13] вважає за необхідне виділення локальних або місцевих порушень, які оцінюються шляхом прямих екологічних спостережень. Н.П. Федоренко та Н.Ф. Реймерс [14] виділяють три просторових рівня екологічних змін - локальний, регіональний і глобальний. На думку авторів, заходи, що використовуються для попередження глобальних та регіональних наслідків, марні в разі проявлення глобальних антропогенних дій.

За спостереженнями дослідника В.А. Павлюшина, імунітет рослин до шкідливих організмів ссрормувався та вдосконалювався в історичному минулому під час утворення та еволюції різних типів біогеоценозів як одного з важливих механізмів їхньої стійкості. Автор вважає, що обов'язковим елементом сучасних технологій рослинництва повинен бути агроекологічний моніторинг наслідків зростаючого антропогенного впливу на агроекосистеми. Такий моніторинг має включати аналіз змін видового, внутрішньовидового та внутрішньопопуляційного біорізноманіття консументів усіх трофрічних рівнів в агроекосистемах, насамперед у домінантних і супердомінантних біотрофів.

Проблеми наслідків антропогенного впливу на екосистеми вивчали науковці В.А. Павлюшин, А.А. Жученко, М.В. Козлов та інші. На думку цих дослідників,масштаби антропогенних змін мають загальнопланетарний характер. Антропогенні перетворення агроекосистем, впливаючи все інтенсивніше на природні біосферні процеси, призводять не тільки до змін характеру дії попередніх екологічних фракторів, але й до появи нових.

У звязку з цим однією з найважливіших задач сучасного періоду антропосоціогенезу є пошук, розроблення і практична реалізація методів попередження та ліквідації негативних змін у глобальній екологічній екосистемі.

Мета. Мета дослідження - узагальнення існуючої ситуації із нераціонального використання пестицидів, аналіз фітосанітарних наслідків антропогенної тран- сформації агроекосистем, оцінювання проблеми застосування засобів захисту у сільському господарстві як фрактора впливу на оточуюче середовище.

Результати досліджень. Накопичені донині у світовій літературі відомості про локальні та регіональні рівні екологічних змін під впливом посиленого антропогенного впливу свідчать про глибокі трансформації як природних, так і штучних екосистем, що відображається на їхній структурно-фрункціональній організації і на динамічних процесах (А.Г. Васильєв; В.А. Павлюшин).

Із розвитком землеробства та рослинництва найбільш дієвим методом вирішення проблеми захисту рослин від негативного впливу шкідливих організмів було і $є$ використання хімічних засобів захисту рослин пестицидів. Однак, не дивлячись на ефективність, їх застосування пов'язане також із небезпекою забруднення навколишнього середовища, погіршення якості продуктів харчування і виникнення ризиків для здоров'я населення. Найнебезпечнішим аспектом застосування пестицидів є фракт, що лише 0,1-1\% цих речовин досягає відповідної цілі, тоді як 99\% потрапляють у грунт, воду, повітря і сільськогосподарські продукти [16; 17].

За даними ЮНЕСКО, пестициди в загальному обсязі забруднення біосфери Землі знаходяться на 8-9 місці після таких речовин, як нафтопродукти, ПАР, фосфрати тощо. Крім того, використання хімічних засобів захисту рослин призводить до забруднення довкілля. Потенційна загроза від їх використання полягає як у гострій токсичності в разі потрапляння в живий організм, так і у хронічній дії, міграції залишків пестицидів водними та повітряними шляхами на значні відстані [18].

Крім того, проблеми виникають через недостатню практику виробництва, транспорту і зберігання пестицидів. Згодом повторне їхнє застосування підвищує опірність шкідників, а їхній вплив на інші види може сприяти відродженню популяції фрітофрагів [19; 20]. Пестициди впливають на навколишнє середовище та екосистеми, призводячи до скорочення біорізноманіття, особливо внаслідок знищення бур'янів і комах, які $€$ важливими елементами харчового ланцюга. Крім того, пестициди негативно впливають на здоров'я людини як унаслідок прямої дії, так і опосередковано внаслідок накопичення залишкових кількостей у сільськогосподарських продуктах і питній воді. Застосування пестицидів може призвести до таких негативних наслідків, як зменшення біологічної продуктивності, порушення функціонування ґрунтових мікробіоценозів, накопичення залишків пестицидів і їх похідних у поверхневих водних джерелах і грунтових водах, перешкода відновленню родючості грунтів, зменшення харчової цінності сільськогосподарської продукції тощо. Загальний ефект використання пестицидів - це зниження видового різноманіття. Зазвичай пестициди також підвищують продуктивність нижніх трофрічних рівнів, знижуючи продуктивність верхHix $[21 ; 22]$

Із ростом застосування пестицидів у багатьох цільових шкідників почала вироблятися стійкість до них, що змушувало виробників збільшувати дози препаратів для боротьби з ними. Хімічні речовини часто знищували не тільки цільових комах, але й корисні види, що 
призвело до нового явища - спалахів чисельності вторинних шкідників: комахи або кліщі, чисельність яких раніше стримували корисні види, почали з'являтися в епізоотичних кількостях. Використовувані пестициди знищували ґрунтові мікроорганізми, які відіграють ключову роль у забезпеченні рослин поживними речовинами, необхідними для росту й розвитку. Інфрільтрація засобів захисту у поверхневі водойми і ґрунтові води почала загрожувати джерелам питної води [23; 24].

Адаптивні підходи в інтегрованій системі захисту рослин, які орієнтують інтенсифікаційні процеси на ресурсо- та енергозбереження та охорону природи, припускають різке скорочення застосування пестицидів за рахунок підвищення ролі механізмів і структур саморегуляції в агроценозах і агроландшафтах. Зі свого боку стратегія застосування хімічних засобів захисту рослин має бути орієнтована на максимальне використання селективно діючих препаратів і технологій, своєчасність проведення заходів, економічну та екологічну доцільність. Важливим елементом удосконалення землеробства $€$ вирощування високопродуктивних сортів сільськогосподарських культур, які характеризуються цінними харчовими, технологічними і товарними якостями, стійкістю до абіотичних і біотичних стресів, визначаючи діяльність шкідливих і корисних організмів в агробіоценозах [25-31].

Важливим механізмом забезпечення біоценотичної стабільності в екосистемах $є$ імуногенетичні властивості як рослин-редуцентів, так і консументів усіх трофічних рівнів. Отримання стабільних урожаїв визначається здатністю рослин забезпечувати фрізіологічний гомеостаз основних продукційних процесів з урахуванням захисно-компенсаторних реакцій на вплив біотичних та абіотичних факторів. Це обумовлено тим, що кожний сорт має специфрічну, генетично закріплену норму реакції на дію різних біотичних та абіотичних стресів [32] А.А. Жученко зазначає, що екологічна стійкість сортів до різного роду стресів, зокрема до пошкодження шкідниками, забезпечується інтегрованістю морфологічних, ростових, фізіолого-біохімічних та інших властивостей рослин та їх збалансованою реалізацією в генотипі. Водночас А.А. Жученко вказує, що жодну ознаку не можна змінити окремо від решти генетичної системи, оскільки незначний добір діє на організм загалом.

Створення стійких до шкідників і хвороб сортів рослин нині $€$ не тільки найважливішою проблемою народногосподарського значення, але і значним екологічно-соціальним завданням. Світова та вітчизняна практика у своєму розпорядженні має широкий арсенал сортів сільськогосподарських культур, стійких до тих чи інших видів шкідливих організмів. Нині серед сортів найважливіших польових культур, які мають Державну реєстрацію в реєстрі селекційних досягнень, насиченість посівних площ стійкими формами рослин $є$ недостатньою і становить близько 7-11\%. Зі світового досвіду відомо, що стабілізуючий ефект у функціонуванні агроекосистем досягається за насичення стійкими формами близько 70-80\% посівної площі певної сільськогосподарської культури. Отже, цей найважливіший резерв підвищення врожайності та екологічної стійкості агробіоценозів повністю не реалізується і не відповідає рішенню завдань оптимізації їх фрітосанітарного стану.

Вирішення проблеми створення генотипів рослин, стійких до біотичних та абіотичних фракторів середовища, пов'язане зі знаннями про структурну організацію імунологічної системи рослин, іï̈ функціонування в агроекосистемах, про механізми імунітету та їх генетичну детермінацію, специфіку взаємин гетеротрофів між собою, про їхній вплив на пошкоджену рослину, характер відповідних реакцій рослини-господаря на вплив комплексів гетеротрофрів, що спричинює необхідність глибокого вивчення складних біологічних систем і надає проведеним у цьому напрямку дослідженням особливої актуальності і своєчасності.

З еволюційних позицій імунітет розглядають у зв'язку з історією виникнення та розвитку механізмів захисту структурної та функціональної цілісності організмів, їхніх органів і тканин, а також як результат спільної еволюції організмів у системі ценозів, виконуючи водночас функції механізму регуляції міжвидових відносин у спільнотах і забезпечуючи тим самим оптимальне функціонування всієї системи [33; 34].

Проблема стійкості рослин до комах значною мірою $€$ біоценотичною, оскільки основу взаємовідносин рослин і комах складають трофічні зв'язки. Встановлено, що бар'єрні фрункції, які обмежують використання біотрофами рослин як джерела живлення і середовища існування, виконують різноманітні ростові, органоутворюючі, морфо-анатомічні, морфоорізіологичні і фрізіолого-біохімічні властивості рослин [25-28]. Вивчення складних взаємозв'язків кормових рослин із фрітофагами, у свою чергу, дозволило обґрунтувати методологію виявлення генотипів, які характеризуються стійкістю до груп і комплексів шкідливих організмів із метою вдосконалення селекційних програм.

Біологічна система «рослина-продуцент - комаха-фрітофаг» - це складна відкрита система, взаємодія партнерів у котрій здійснюється за принципом прямих (речових та енергетичних) і зворотних (інформаційних) зв'язків. Необхідно враховувати певний характер взаємодії комах і рослин, який визначається двояким значенням останніх: будучи компонентом агробіоценозу, вони відіграють роль екзогенного фрактора відносно фритофрагів, а використання рослин комахами як джерела їжі надає їм значення ендогенного фактора [27-29].

Екологічна своєрідність системи «рослина-продуцент - комаха-фрітофраг» в агробіоценозах визначається необхідністю періодичного поновлення взаємозв'язків між ії елементами. Під час взаємодії фрітофагів із сільськогосподарськими культурами внаслідок їхньої ротації відбувається постійна зміна стацій. Зміни в сортовому складі різних сільськогосподарських культур, що здійснюються 3 метою підвищення їх продуктивності, істотно впливають на абіотичні умови в агробіоценозах і біотичні зв'язки рослин з існуючими шкідливими та корисними видами [25-27].

Фітосанітарні наслідки порушення ентомоценозів агроекосистем

Порушення екосистем унаслідок господарської діяльності людини наразі призвело до руйнування при- 
родних екосистем на великих площах та виникнення антропогенних ландшафтів із переважанням рудеральної рослинності та збідненим складом флори і фауни. На думку М.В. Козлова [28; 29], у районах інтенсивної антропогенної дії можна виявити випадки порушення перебігу еволюції; це дозволяє припустити, що дія людини на природу насправді наближує планету до нової біоценотичної кризи.

Пестициди в ролі міцного цілеспрямованого фактора в агроценозах скорочують невисоке видове різноманіття екосистем, причому насамперед елімінуються корисні для людини види. Результатом цього є зниження міжвидової конкуренції та послаблення регуляції паразитами й хижаками. Широкомасштабне застосування пестицидів за останні 20-25 років супроводжується збільшенням кількості резистентних видів комах до пестицидів (30).

Для успішного захисту сільськогосподарських рослин від шкідників необхідне знання генетичної структури популяцій, динаміки міграційних процесів, акліматизаційних і поведінкових реакцій, умов розмноження, співвідношення статей і трофічних зв'язків як шкідливих, так і корисних комах.

Триваюче повсюдне використання хімічних інсектицидів (особливо піретроїдів і ФОС) у деяких агроекосистемах призвело до розвитку резистентності не тільки цільових фрітофагів, але й у природних популяціях ентомофрагів і акарифрагів, які контролюють їхню чисельність. Зокрема, основними факторами розвитку резистентності шкідників до фросфорорганічних сполук $є$ посилення захисної ролі покривів членистоногих (інгібітори синтезу хітину), зниження чутливості до препаратів основної мішені їх дії - ацетилхолінестерази (інгібітори АХE), посилення процесів ферментативної детоксикації інсектицидів. Резистентність до піретроїдів, як вважають, обумовлена насамперед зменшенням чутливості нервової системи комах [32-36].

Унаслідок цього стали нормою спалахи розмноження не тільки окремих видів фрітофагів, але і їхніх комплексів. Зареєстрована втрата токсичності піретроїдних і фоссророрганічних препаратів щодо небезпечного шкідника зернових культур - клопа шкідливої черепашки. Практики змушені використовувати їхні сумішеві комбінації, але довготривалого ефекту цей захід не приносить. Виявлено також формування резистентності в популяціях італійського Пруса, перелітної азіатської сарани, кобили хрестової, що породжує нові проблеми в боротьбі з цими масовими багатоїдними шкідниками. Наслідком цього стало збільшення норм витрачання інсектицидів, кратності обробок посівів і посадок, і водночас - зниження їх ефективності, збільшення втрат урожаю, підвищення екологічного ризику. Фактично створилася нова ситуація, коли під час підбору методів і засобів боротьби орієнтація тільки на домінантні види вимагає серйозних коректив.

Реакція комах на антропогенну дію проявляється на трьох рівнях організації: організменому, популяційно-видовому та екосистемному. Зазвичай не існує специфічних відповідних реакцій на той чи інший тип антропогенної дії: наприклад, зміна подовженості розвитку може виникати у відповідь на порушення середо- вища існування, водного і світлового режиму, а також на вплив пестицидів. Найчастіше виникає зміна чисельності (щільності) популяції окремих видів.

Зміни взаємовідносин у системі «фітофаг-кормова рослина» у відповідь на зміну рослини під дією антропогенних порушень потребують постійного вивчення із врахуванням усіх фракторів стійкості рослини до фрітофрагів.

Зміни, що відбуваються в популяціях комах за антропогенної дії, можуть бути використані для контролю стану природного середовища, що зумовлює необхідність використовувати принципи фрілогенетичного прогнозу для популяцій комах та облік антропогенної модифікації еволюційних процесів під час складання екологічних прогнозів для популяцій комах.

Порушення водного режиму екосистем у більшості випадків має цілеспрямований характер та пов'язано з проведенням меліоративних робіт: осушенням перезволожених і зрошенням посушливих земель. Наукові відомості про вплив водного балансу на популяції наземних комах відображають насамперед зміни, що відбуваються в агроценозах за різних режимів зрошення ґрунтів.

Слід ураховувати, що всі заходи зі зрошення чи осушення земель супроводжуються істотними змінами мікроклімату, зокрема у приземних шарах повітря та верхніх горизонтах ґрунту; змінюється структура, щільність, хімічний, видовий і фізіологічний склад рослин.

На організменому рівні під впливом зволоження відбувається збільшення термінів розвитку деяких видів шкідників [37], на популяційно-видовому - зміни чисельності окремих груп, що пов'язано як зі зміною вологості середовища існування, так і з пригніченням розвитку кормових рослин. Вологість найсильніше впливає на різні групи грунтових видів [38].

Зрошення ґрунтів суттєво впливає на порушення видового різноманіття ентомоценозів. У працях В.М. Стовбчатого міститься інформація про зникнення ксерофрільних видів після початку зрошення. Крім того, відбувається збільшення чисельності видового складу та біомаси комах, перебудовуються трофрічні зв'язки, змінюється перебіг розвитку окремих видів унаслідок подовження або зникнення діапаузи. Одночасно зі зміною видового складу функціональних груп в агроекосистемах відбуваються також відчутні зміни біології низки домінуючих видів консументів [39].

Висновки. Загалом наведені в цій публікації матеріали свідчать про необхідність регулярного проведення біологічного моніторингу екологічних наслідків зростаючої антропогенної дії на агроекосистеми як обов'язкового елемента сучасних технологій рослинництва. Такий моніторинг повинен передбачати аналіз змін видового, внутрішньовидового біорізноманіття консументів в агроекосистемах. Отримані результати слід обов'язково враховувати під час розроблення зональних систем екологізованої системи захисту рослин із метою забезпечення високої ефективності захисних заходів. Це потребує принципово нових підходів до вирішення проблеми, включаючи розроблення автоматизованого 
прогнозу зміни чисельності домінуючих видів фрітофагів на різних етапах онтогенезу культур під дією різних екзогенних впливів.

Значення пестицидів як забруднювачів екологічної системи повністю доведено, проте вивчення цього питання залишається актуальним і нині. Найважливішими фракторами, що запобігають зменшенню забруднення навколишнього середовища, $€$ скорочення норм витрат препаратів шляхом стрічкового або локального внесення і кратності їх застосування, вирощування стійких сортів та гібридів, застосування біологічних препаратів, альтернативних методів внесення пестицидів. Тому виникає необхідність регулярного моніторингу резистентності шкідливих організмів, регламентації хімічного методу, залучення до систем захисту рослин сучасного набору біологічних засобів, освоєння стратегії і тактики біоценотичного контролю, впорядкування агрозаходів, здатних загальмувати мікроеволюційні процеси в популяціях шкідливих видів під впливом пестицидів.

Отже, задля уникнення негативних фрітосанітарних наслідків для агроекосистем система захисту польових культур має базуватися на принципах екологічної безпеки з визначенням оптимального рівня і критеріїв антропогенного навантаження за стійкого функціонування агроландшафртів. Технології захисту мають сприяти посиленню стабілізуючого добору в популяціях шкідливих видів фауни і фрлори, механізмів регуляції їх чисельності. Рекомендації щодо використання нових методів та засобів захисту рослин мають базуватися на результатах оцінки ризику можливих негативних наслідків їх застосування.

\section{СПИСОК ВИКОРИСТАНОÏ ЛІТЕРАТУРИ:}

1. Артиш В. І. Порівняльна оцінка інтенсивного та екологічно чистого ведення сільського господарства. Економіка АПК. 2005. № 10. С. 20-23.

2. Новожилов К. В. Проблемы оптимизации фитосанитарного состояния растениеводства. Сельскохозяйственная биология. 1997. № 5. С. 28-38.

3. Герасимчук А. А., Куценко О. М., Писаренко В. М., Рабштина В.М. Соціально-економічні проблеми аграрної сфери виробництва: Конспекти лекцій Київ, 1993. 79 с.

4. Кірейцева О. В., Сокол Л. М. Екологічні аспекти сільськогосподарського виробництва. Економіка АПК. 2017. № 7. С. 29-36. URL: http://nbuv.gov.ua/ UJRN/E_apk_2017_7_6

5. Рамад Ф. Основы прикладной экологии. Ленинград, 1981. $572 \mathrm{c}$.

6. Воейков А. И. Новейшие исследования ледников и причин их изменений. Избранные сочинения. Москва : АН СССР, 1881. Т. III. С. 365-375.

7. Вернадский В. И. Биосфера. Москва : Мысль, 1967. $374 \mathrm{c}$

8. Марш Дж. Человек и природа, или о влиянии человека на изменения фризико-географических условий природы [пер. с англ.]. СПб. : Человек и природа, 1864. 587 с.

9. Васильєв А. Г., Васильєва І. А. Епігенетичні перебудови популяцій як ймовірний механізм настання біоценотичного кризу. Вісник Нижегородського держ. ун-ту ім. Н.М. Лобачевського. Серія Біологія. 2005. № 1 (9). C. 27-38.

10. Вилкова Н. А., Иващенко Л. С. Иммунитет растений к вредителям и его роль в биорегуляции агроэкосистем. Труды РЭО. 2001. №. 72. С. 74-75.

11. Гирусов Э. В. Экологическое сознание как условие оптимизации взаемодействия общества и природы. Философские проблемы глобальной экологии. Москва : Наука, 1983. С. 105-120.

12. Городков К. Б. Динамика ареалов насекомых под антропогенным воздействием. Проблемы энтомологии в России. Труды РЭО. 1998. № 1. С. 93-94.

13. Жученко А. А. Экологическая генетика культурных растений и проблемы агросферы (теория и практика): монография: в двух томах. Москва, 2004. Toм I. $690 \mathrm{c}$

14. Федоренко Н. П., Реймерс Н. Ф. Экология и экономика - эволюция взаимоотношений. От «экономии» природы до «большой» экологии. Философские проблемы глобальной экологии. Москва 1983. C. 230-277.

15. Рогозин, М. Ю., Бекетова Е. А. Экологические последствия применения пестицидов в сельском хозяйстве. Молодой ученый. 2018. № 25 (211). С. 39-43.

16. Waid J.S. PCBs and the Environment : book in Vols. I-III. Boca Raton, 1987. Vol. 1. 120 c.

17. ToxFAQs: Polychlorinated Biphenyls. Agency for Toxic Substances and Disease Registry (ATSDR). Atlanta, 1997. URL: http://atsdr1.atsdr.cdc.gov:8080/tfacts17.html.

18. Охорона водного середовища. urokof.net. URL: http://urokof.net/?id=NzQ0

19. Damalas C.A.; Eleftherohorinos, I.G.Pesticide Exposure, Safety Issues, and Risk Assessment Indicators. International Journal of Environmental Research and Public Health. 2011. № 8 (12). P. 1402-1419. URL: http://www.mdpi.com/1660-4601/8/5/1402

20. Darrin Lew. Effects of Herbicides and Pesticides on Aquatic Life. Plant Adaptation: www.drdarrinlew.us. 2018. URL: https://www.drdarrinlew.us/plant-adaptation/ effects-of-herbicides-and-pesticides-on-aquatic-life. html

21. Environmental impacts of pesticides. SLU: www.slu.se. 2016. URL: https://www.slu.se/en/CollaborativeCentres-and-Projects/centre-for-chemical-pesticidesckb1/information-about-pesticides-in-the-environment-/ exposure-and-environmental-impact

22. What Happens to Pesticides Released in the Environment? National Pesticide Information Center. npic.orst.edu. 2017. URL: http://npic.orst.edu/envir/ efate.html

23. Каменченко С. Е. Пути совершенствования интегрированной защиты орошаемых посевов в Поволжье. Защита растений в условиях реформирования агропромышленного комплекса: экономика, эффрективность, экологичность: тезисы докладов. СПб., 1995. С. 126.

24. Куценогий К. П., Киров Е. И., Кнор И. Б., Алексеев А. А. Пестициды в экосистемах: проблемы и перспективы. Новосибирск, 1994. 142 с.

25. Вилкова Н.А., Нефедова Л.И. Структурнофункциональная организация иммуногенетической системы мятликовых и ее влияние на взаимосвязи с вредными организмами в агроэкосистемах. Вестник защиты растений. 2015. № 2 (84). С. 13-20. 
26. Shapiro I.D. Ecological bases of plant protection against pests at intensive technology cultivation of crops on the example of grain and leguminous crops. Leningrad LSKhl, 1988. 73 p.

27. Shapiro I.D. Immunity of field cultures to insects and mites. Leningrad, 1985. $321 \mathrm{p}$.

28. Shapiro I. D., Vilkova N. A. Grades of crops resistant to pests - the most important factor of improvement of phytosanitary situation in 20 agrobiocenoses. Sel'skokhozyaistvennaya biologiya, seriya "Biologiya rastenii». 1989. № 3. P. 98-103.

29. Павлюшин В. А. Антропогенная трансформация агроэкосистем и ее фитосанитарные последствия. СПб., 2008. 119 c.

30. Pavlyushin V. A., Vilkova N. A., Sukhoruchenko G. I., Nefedova L. I., Fasulati S. R. Phytosanitary destabilization of agroecosystems. St Petersburg, 2013. 184 p.

31. Вилкова Н. А., Иващенко Л. С. Иммунитет растений к вредителям и его роль в биорегуляции агроэкосистем. Труды РЭО. 2001. 72. С. 129-144.

32. Жученко А. А. Экологическая генетика культурных растений и проблемы агросферы (теория и практика). Москва, 2004. Т. 1-2. 1156 с.

33. Козлов М. В. Ответные реакции популяций насекомых на антропогенные воздействия. Красноярск, 1987. $60 \mathrm{c}$.

34. Козлов М. В. Влияние антропогенных фракторов на популяции наземных насекомых. Итоги науки и техники: Энтомология. Москва, 1990. Т. 13. 192 с.

35. Рославцева С. А. Распространение резистентных к инсектоакарицидам популяций членистоногих в мире. Агрохимия. 1988. № 2. С. 121-136.

36. Киль В. И. Резистентность к инсектицидам. Молекулярные маркеры в защите сельскохозяйственных растений от вредных насекомых. Защита и карантин растений. 2010. № 9. С. 21-24.

37. Миноранский В. А. Защита орошаемых полевых культур от вредителей. Москва, 1989. 208 с.

38. Трухан М. Н. Изменение структуры фраунистических комплексов кровососущих двукрылых под влиянием осушительной мелиорации. Наука и техника: Влияние хозяйственной деятельности человека на беспозвоночных. Минск, 1980. С. 124-138.

39. Стовбчатый В. Н. Влияние водной мелиорации на почвообитающих насекомых. Киев, 2000. 62 с.

\section{REFERENCES :}

1. Artysh, V.I. (2005). Porivnialna otsinka intensyvnoho ta ekolohichno chystoho vedennia silskoho hospodarstva [Comparative assessment of intensive and environmentally friendly agriculture]. Ekonomika APK, 10, 20-23. [in Ukrainian].

2. Novozhylov, K.V. (1997). Problemy optymyzatsii fitosanitarnoho stanu roslynnytstva [Problems of optimization of the phytosanitary state of plant growing] Selskokhoziaistvennaia byolohyia, 5, 28-38. [in Russian].

3. Herasymchuk, A.A., Kutsenko, O.M., Pysarenko, V.M., \& Rabshtyna, V.M. (1993). Sotsialnoekonomichni problemy ahrarnoi sfery vyrobnytstva: Konspekty lektsii [Socio-economic problems of the agricultural sphere of production: Lecture notes]. Vol. 10. Kyiv: NMK VO. [in Ukrainian].

4. Kireitseva, O.V., \& Sokol, L.M. (2017). Ekolohichni aspekty silskohospodarskoho vyrobnytstva [Ecological aspects of agricultural production]. Ekonomika APK, 7, 29-36. [in Ukrainian].

5. Ramad F. (1981). Osnovy prikladnoy ekologii [Fundamentals of applied ecology]. Leningrad: Hydrometeoyzdat. [in Russian].

6. Voeikov, A. Y. (1881). Noveishye yssledovanyia lednykov y prychyn ykh yzmenenyi. Yzbrannye sochynenyia [The latest research on glaciers and the reasons for their changes. Selected works]. Vol. 3. Moscow: AN SSSR. [in Russian].

7. Vernadskyi, V. Y. (1967). Byosfera [Biosphere]. Moscow: Mysl'. [in Russian].

8. Marsh, J.P. (1864). Man and Nature; Or, Physical Geography as Modified by Human Action. London: S. Low, Son and Marston.

9. Vasyliev, A.H., \& Vasylieva, I.A. (2005). Epihenetychni perebudovy populiatsii yak ymovirnyi mekhanizm nastannia biotsenotychnoho kryzu [Epigenetic population rearrangements as a probable mechanism of biocenotic crisis]. Visnyk Nyzhehorodskoho derzh. un-tu im. N.M. Lobachevskoho, Ser. Biology, 1 (9), 27-38 [in Ukrainian].

10. Vylkova, N.A., \& Yvashchenko, L.S. (2001). Ymmunytet rastenyu $\mathrm{k}$ vredytelyam y ego rol $v$ byoreguliacyy agroekosystem [Plant immunity to pests and its role in the bioregulation of agroecosystems]. Trudy REO, 72, 74-75. [in Russian].

11. Gyrusov, E.V. (1983). Ekologycheskoe soznanye kak uslovye optymyzatsyy vzaemodeistvyia obshchestva y pryrodu [ Environmental Consciousness as a Condition for Optimizing the Interaction between Society and Nature.] Fylosofskye problemy globalnoy ekologyy. Moscow: Nauka. [in Russian].

12. Gorodkov, K.B. (1998). Dynamyka arealov nasekomuh pod antropogennum vozdeistvyem. Problemyi entomologyy $v$ Rossyy [Dynamics of insect habitats under anthropogenic impact. Problems of entomology in Russia]. Trudu REO, 1, 93-94. [in Russian].

13. Zhuchenko, A. A. (2004). E’kologicheskaya genetika kul'turny`kh rastenij i problemy` agrosfery` (teoriya i praktika): monografiya [Ecological genetics of cultivated plants and problems of agrosphere (theory and practice): monograph.]. Vol. I. Moscow : OOO Izdatelstvo Agrorus. [in Russian].

14. Fedorenko, N. P., \& Rejmers, N. F. (1983). E`kologiya i e`konomika - e`volyucziya vzaimootnoshenij. Ot «e`konomii» prirody` do «bol'shoj» e'kologii [Ecology and economics - the evolution of relationships. From "economy" of nature to "big" ecology]. Filosofskie problemy` global 'noj e `kologii. Moscow: Nauka, 230-277.

15. Rogozin, M. Yu., \& Beketova, E. A. (Ed.). (2018). E'kologicheskie posledstviya primeneniya pesticzidov $v$ sel'skom khozyajstve [Environmental Effects of Pesticide Use in Agriculture]. Molodoj ucheny `j, 25 (211), 39-43. [in Russian].

16. Waid, J.S. (1987). PCBs and the Environment. Vols. I-III. Boca Raton, FL: CRC Press.

17. ToxFAQs: Polychlorinated Biphenyls. (1997). Agency for Toxic Substances and Disease Registry (ATSDR). USA, Atlanta, Georgia, Retrieved from: http://atsdr1. atsdr.cdc.gov:8080/tfacts $17 . \mathrm{html}$.

18. Okhorona vodnoho seredovyshcha. (n.d.). urokof. net. Retrieved from: http://urokof.net/?id=NzQ0 [in Ukrainian]. 
19. Damalas, C. A., \& Eleftherohorinos, I. G. (2011). Pesticide Exposure, Safety Issues, and Risk Assessment Indicators. International Journal of Environmental Research and Public Health, 8 (12), 1402-1419. Retrieved from: http://www.mdpi.com/ $1660-4601 / 8 / 5 / 1402$

20. Lew, Darrin (2018). Effects of Herbicides and Pesticides on Aquatic Life. Plant Adaptation. https://www.drdarrinlew.us. Retrieved from: https://www.drdarrinlew.us/ plant-adaptation/effects-of-herbicides-and-pesticideson-aquatic-life.html

21. Environmental impacts of pesticides. (2016). (n.d.). www.slu.se. Retrieved from: https://www. slu.se/en/Collaborative-Centres-and-Projects/ centre-for-chemical-pesticides-ckb1/information-about-pesticides-in-the-environment-/ exposure-and-environmental-impact

22. What Happens to Pesticides Released in the Environment? (2017). National Pesticide Information Center. npic.orst.edu. Retrieved from: http://npic.orst. edu/envir/efate.html

23. Kamenchenko, S.E. (1995). Puti sovershenstvovaniya integrirovannoj zashhity oroshaemy'kh posevov $v$ Povolzh`e [Ways to improve the integrated protection of irrigated crops in the Volga region]. Zashhita rastenij $v$ usloviyakh reformirovaniya agropromy'shlennogo kompleksa: e 'konomika, e'ffektivnost', e'kologichnost'. Tezisy` dokladov, SPb., 126. [in Russian].

24. Kuczenogij, K.P., Kirov, E.I., Knor, I.B., \& Alekseev, A.A. (1994). Pesticzidy` v e`kosistemakh: problemy` i perspektivy [Pesticides in ecosystems: problems and prospects]. Novosibirsk: SO RAN. GPNTB. In-t khim. kinetiki i goreniya. In-t biologii. [in Russian].

25. Vilkova, N.A., \& Nefedova, L.I. (2015). Strukturnofunkczional'naya organizacziya immunogeneticheskoj sistemy` myatlikovy 'kh i ee vliyanie na vzaimosvyazi s vredny”mi organizmami v agroe "kosistemakh [Structural and functional organization of the immunogenetic system of bluegrass and its influence on the relationship with harmful organisms in agroecosystems]. Vestnik zashhity` rastenij, 2(84), 13-20. [in Russian].

26. Shapiro, I.D. (1988). Ecological bases of plant protection against pests at intensive technology cultivation of crops on the example of grain and leguminous crops. Leningrad: LSKhl.

27. Shapiro, I.D. (1985). Immunity of field cultures to insects and mites. Leningrad: ZIN AN SSSR.

28. Shapiro, I.D., \& Vilkova, N.A. (1989). Grades of crops resistant to pests - the most important factor of improvement of phytosanitary situation in 20 agrobiocenoses. Sel'skokhozyaistvennaya biologiya, Seriya Biologiya rastenii, 3, 98-103.

29. Pavlyushin, V.A. (2008). Antropogennaya transformacziya agroe`kosistem i ee fitosanitarny`e posledstviya. SPb.[in Russian].

30. Pavlyushin, V.A., Vilkova, N.A., Sukhoruchenko, G.I., Nefedova, L.I., \& Fasulati, S.R. (2013). Phytosanitary destabilization of agroecosystems. St Petersburg: NPPL Rodnye prostory. [in Russian].

31. Vilkova, N.A., \& Ivashhenko L.S. (2001). Immunitet rastenij $\mathrm{k}$ vreditelyam i ego rol $\mathrm{v}$ bioregulyaczii agroe 'kosistem [Plant immunity to pests and its role in the bioregulation of agroecosystems]. Trudy ' $R E^{\prime} O, 72,129-144$. [in Russian].
32. Zhuchenko A. A. (2004). E`kologicheskaya genetika kul'turny'kh rastenij i problemy' agrosfery' (teoriya i praktika) [Ecological genetics of cultivated plants and problems of the agrosphere (theory and practice)]. Vol. 1-2. Moscow: Agro- rus. [in Russian].

33. Kozlov, M.V. (1987). Otvetny`e reakczii populyaczij nasekomy'kh na antropogenny`e vozdejstviya [Response reactions of insect populations to anthropogenic influences].Krasnoyarsk: Preprint/ILiD SO AN SSSR. [in Russian].

34. Kozlov, M.V. (1990). Vliyanie antropogenny kh faktorov na populyaczii nazemny`kh nasekomy`kh [Influence of anthropogenic factors on the populations of terrestrial insects]. Itogi nauki i tekhniki: E'ntomologiya, Iss. 13. [In Russian].

35. Roslavczeva, S.A. (1988). Rasprostranenie rezistentny ${ }^{` k h} \mathrm{k}$ insektoakariczidam populyaczij chlenistonogikh $\checkmark$ mire [Distribution of arthropod populations resistant to insectoacaricides in the world]. Agrokhimiya, 2, 121-136. [in Russian].

36. Kil', V.I. (2010). Rezistentnost' k insekticzidam. Molekulyarny`e markery` v zashhite sel`skokhozyajstvenny`kh rastenij ot vredny 'kh nasekomy `kh [Insecticide resistance. Molecular markers in the protection of agricultural plants from harmful insects]. Zashhita $i$ karantin rastenij, 9, 21-24. [in Russian].

37. Minoranskij, V.A. (1989). Zashhita oroshaemy`kh polevy'kh kul'tur ot vreditelej [Protection of irrigated field crops from pests.]. Moscow: Agropromizdat. [in Russian].

38. Trukhan, M. N. (1980). Izmenenie struktury` faunisticheskikh kompleksov krovososushhikh dvukry”ly”kh pod vliyaniem osushitel'noj melioraczii [Changes in the structure of faunistic complexes of blood-sucking dipterans under the influence of drainage reclamation]. Vliyanie khozyajstvennoj deyatel'nosti cheloveka na bespozvonochny`kh. Minsk: Nauka i tekhnika, 124-138. [in Russian].

39. Stovbchaty j, V. N. (2000). Vliyanie vodnoj melioraczii na pochvoobitayushhikh nasekomy'kh [Influence of water reclamation on soil insects]. Kiev: Izdatel'stvo Znania Ukrainy. [in Russian].

Мельничук Ф.С., Гордієнко О.В., Алєксєєва С.А., Острик І.М., Шатковська К.Б., Гуленко О.І. Фітосанітарні наслідки антропогенної трансформації агроекосистем

Мета дослідження - узагальнення існуючої ситуації щодо нераціонального використання пестицидів та аналіз фрітосанітарних наслідків антропогенної трансформації агроекосистем; оцінювання проблеми застосування засобів захисту рослин у сільському господарстві як факторів впливу на оточуюче середовище. Результати. У статті узагальнено відомості про динамічні процеси, що відбуваються в екосистемах різних типів, зокрема в агробіоценозах, що свідчить про трансформацію їх структурно-функціональної організації під впливом посилених антропогенних фракторів. Проведено наукове обґрунтування нових методологічних і методичних підходів до обмеження чисельності і шкідливості небезпечних видів біотрофрів та запобігання негативним екологічним наслідкам. Проаналізовано стратегічні основи застосування хімічних засобів захисту рослин, які, у свою чергу, повинні бути спрямовані на максимальне 
використання селективно діючих препаратів і технологій, на своєчасність проведення заходів, економічну та екологічну доцільність. Наведено основні аспекти забезпечення стабільно високих урожаїв за рахунок урахування захисно-компенсаторних реакцій на вплив біотичних та абіотичних факторів.

Розкрито умови, особливості та загальні закономірності послідовного ускладнення фрітосанітарної обстановки і відгуки ентомофрауни на сучасні технології землекористування й захисту рослин. Показано, що нарощуване застосування хімічних засобів тягне за собою зниження їх ефективності через формування резистентності до них популяцій шкідників і збудників хвороб вирощуваних культур. Головними у стратегії і тактиці збереження врожаю визнані такі заходи: оперативний моніторинг, упорядкування агротехніки, регламентація хімічного методу, переважне застосування біологічних засобів, активізація механізму природної саморегуляції. Висновки. Викладено основні принципи розроблення систем захисту сільськогосподарських рослин від шкідників, що базуються на необхідності знання генетичної структури популяцій, динаміки міграційних процесів, акліматизаційних і поведінкових реакцій, умов розмноження, співвідношення статей і трофрічних зв'язків як шкідливих, так і корисних видів комах.

Ключові слова: екосистеми, агробіоценози, антропогенні фрактори, фітосанітарна оптимізація агроекосистем, саморегуляція ентомокомплексів, зрошування.

Melnychuk F.S., Hordiienko O.V., Alekseeva S.A., Ostryk I.M., Shatkovska K.B., Gulenko O.I. Phytosanitary consequences of agroecosystems' anthropogenic transformation

Goal. To generalize the current situation regarding the irrational use of the pesticides and to analyze the phytosanitary consequences of agroecosystems's anthropogenic transformation; assess the problems of protection in agriculture as a factor influencing the environment. Results. The article summarizes information about the dynamic processes occurring in ecosystems of different types, including agricultural ecosystems, which indicates the transformation of their structural and functional organization under the influence of enhanced anthropogenic factors. Scientific substantiation of new methodological and methodical approaches to limiting the number and harmfulness of dangerous species of biotrophs and prevention of negative environmental consequences has been carried out. The strategic bases of application of chemical plant protection products are analyzed, which in turn should be focused on the maximum use of selectively acting drugs and technologies, timeliness of measures, economic and environmental feasibility. The main aspects of ensuring consistently high yields by taking into account the protective and compensatory reactions to the influence of biotic and abiotic factors.

The conditions, features, and general regularities of consistent complication of phytosanitary situation and responses of entomologic fauna to modern technologies of land use and plant protection are revealed. It is shown that the increasing use of chemicals entails a decrease in their effectiveness due to the formation of resistance to them in populations of pests and pathogens of crops. The main the strategy and tactics of crop conservation are: operational monitoring, streamlining of agricultural machinery, regulation of the chemical method, the predominant use of biological agents, and the activation of the mechanism of natural self-regulation.

Conclusions. The basic principles of development of systems of protection of agricultural plants against pests are based on the necessity of knowledge of the genetic structure of populations, migration processes (dynamics), acclimatization, behavioral reactions, conditions of reproduction, the ratio of sexes, and trophic communications of both harmful and useful species of insects are stated.

Key words: ecosystems, agricultural biocenoses, anthropogenic factors, phytosanitary optimization of agroecosystems, self-regulation of entomological complexes, irrigation. 